\title{
I I
}

\section{Innocents Abroad}

Sharon said, when she came back, "I feel as if I was cheated. I was going there to meet people like you."

- Lucinda Talbot

The encampment invited women of all political, sexual, philosophical, ethnic, racial, and religious persuasions to join in the summer of protest. Since the encampment did not collect reliable information on the backgrounds of the women who attended, however, it is impossible to know the range of differences among them. Nevertheless, one incident suggests both that different kinds of women did indeed come to the encampment and that the encampment was not always able to deal with the significant differences that appeared in its community.

Early in July, Sharon Chapman and Lucinda Talbot, both from Elmira, New York, held an impromptu press conference on the encampment's front lawn to explain their reasons for leaving. Unlike most women, who came and went quietly and somewhat anonymously throughout the summer, announcing their arrival and departure only to friends and lovers, Chapman and Talbot gave the public news media vivid accounts of their encampment experiences.

By July Io these two women, who had arrived for the encampment's opening on July 4 and had participated in encampment activities for the whole first week, felt strongly that they wanted and needed to leave. During the week following their departure, accounts appeared in several local newspapers about Talbot's and Chapman's experiences, in which the women explained that they had left the encampment because of their 
revulsion against the unpatriotic "lesbian-vegetarian-witches" there, who also desecrated the American flag. The Ithaca Journal article, which appeared on July I 2 under the headline "Two Leave Romulus Women's Camp, Claiming Members Practice Witchcraft," was typical:

Two Elmira women left the Women's Encampment for a Future of Peace and Justice in Romulus Sunday, claiming protestors there called themselves witches and are "intolerant."

Lucinda Talbot, 31, said she and Sharon Chapman, 32, were criticized when the two objected to women stamping on an American flag.

Talbot said they were disturbed with activities in the camp, including what she described as singing in a circle and howling. Many women wore necklaces with double axe blade pendants that the women said was a symbol of worship, she said.

"They told us it was witchcraft," Talbot said.

She said the women had woven colored yarn "as a way of increasing their power."

But camp member Diana Mueller of Burlington, Vt., said the weaving is an expression of unity among different viewpoints in the camp.

Another camp member, who identified herself as Shad, said the pendants are an ancient symbol of matriarchal history. She said some of the camp members practice what they call witchcraft, but she added, "There's a big difference between Satanism and white witchcraft."

Ann Jochems, of Brooktondale, said Talbot and Chapman did not get along with "committed" camp members. With no official directors at the camp, "It's hard not to have strong leaders emerge," she said.

The two women spent about a week in the camp, and by last weekend were unable to converse with the other camp members, Jochems said.

Talbot, a Quaker, said the women "worship a goddess" and are "very much opposed to God."

"They are tolerant of their own beliefs, and if you don't believe what they do, they put you down for it," she said.

Talbot said that at a consensus meeting, the women agreed not to desecrate the American flag. But later, she said, she found some women stamping on a flag.

She said she objected to the flag "desecration" because "Some Sisters that are feminists and pacifists do believe in this country."

Talbot said she plans to form a group in Elmira "to pray for the camp."

The stories Talbot and Chapman told about what they found frightening, perverse, and threatening about the encampment spread rapidly the first week after the encampment opened. Because the Elmira women had, 
at least temporarily, been encampment insiders, their accounts seemed to provide a unique view of previously hidden aspects of the encampment activities.

Chapman and Talbot felt their problems with encampment women had begun even before they got to Romulus. When a group of women who were walking from North Carolina to the encampment for the opening ceremonies passed through Elmira, Talbot and Chapman had joined the marchers. The other women had set a pace that the two from Elmira couldn't match, had refused to talk to Chapman and Talbot, and had offered them unappealing food to eat. Talbot and Chapman were soon hot, tired, sore, and discouraged. They decided to abandon the marchers and drove to the encampment, but when they arrived they were told that they could not drive their car to the back camping area but had to carry all their equipment and possessions by hand. Soon, physical trials and discomfort gave way to a sense of alienation as Chapman and Talbot became aware that feminist spirituality, witchcraft, vegetarianism, and lesbianism were practiced at the encampment and that many participants harbored what the two from Elmira considered to be anti-American sentiments. Chapman and Talbot freely associated these practices, assuming that they were related because they all occurred in the same place:

Talbot: Unless I saw somebody kissing somebody or they happened to mention that they were a lesbian witch, I didn't call them a lesbian witch unless they told me so.

Question: You're making a connection between the term lesbian and witch; if a person was one, were they the other?

Talbot: Usually.

Question: Yea?

Talbot: I don't think there were any heterosexual witches.

Chapman: No, I don't think so.

Talbot: I mean I saw one witch who wasn't vegetarian, or if she was she was maybe trying to wean herself off meat, I don't know, cause she was eating vegetable beef soup. And she blushed when I mentioned it to her; so she probably was trying to wean herself off meat.

In connecting lesbianism and witchcraft to food, the two women were employing a common code for talking about what appeared to be some- 
what shocking and unfamiliar subjects. They could use food sharing, food preferences, and the symbolic use of mealtimes as a shorthand to convey some of the dramatic differences they perceived between their own habits and those of the encampment. Food provides a particularly telling device for voicing differences because it is a conventionalized way to express concerns about larger social issues. According to anthropologist Mary Douglas, "If food is treated as a code, the messages it encodes will be found in the pattern of social relations being expressed. The message is about different degrees of hierarchy, inclusion and exclusion, boundaries and transactions across boundaries. Like sex, the taking of food has a social component, as well as a biological one. Food categories therefore encode social events" (1975:249). Through food codes we feel we can see and judge various political, social and cultural tastes and inclinations. What people eat is thought to be a good sign of who they are. As Sidney Mintz explains, human beings believe that "food preferences are close to the center of their self-definition: people who eat strikingly different foods, or similar foods in different ways are thought to be strikingly different, sometimes even less human" (I 985:3). Chapman and Talbot took the food habits of the encampment as an indication of who the encampment women "really" were and what relationship could be developed with them.

The two attributed the distaste they felt for the encampment's food choices to a fundamental disagreement over food preferences. The encampment favored vegetarianism, but Chapman and Talbot considered themselves omnivores. Talbot explained: "They called people who weren't vegetarians carnivores. I tried to explain to them that it was omnivore for the simple reason that human beings do eat vegetables too." Talbot and Chapman thus identified the normal human being as omnivorous and perceived vegetarianism as somewhat abnormal. They complained about the blandness and unfamiliarity of vegetarian meals and worried about the potential nutritional dangers of avoiding meat:

Chapman: The meals were very bad, really. We're talking serious nutrition now.

Talbot: Well, you've got to remember too that they were cooking over an open fire.

Chapman: Yeah, they had some potato salad, at least they alleged it was potato salad, but it tasted like they dumped vinegar on it. And they had 
stuff with a lot of curry in it, and that tasted kind of weird too. And you know, before we even went up there we asked and we were assured that there would be provisions made for people who liked to eat meat. And after we got there we were told that "we don't like to slaughter animals for food; therefore you can't have meat because it offends some of us."

Talbot: I was told the smell of cooking meat offends them. And it wouldn't hurt people to eat a vegetarian diet. And it doesn't hurt people to eat a vegetarian diet provided that they follow the balanced food group type of thing.

Chapman: And that wasn't available there, I know enough about nutrition to know that it wasn't.

The dangers of being required against one's will to eat such foods are multiple. When the food is unfamiliar and alien ("At least they alleged it was potato salad"); incorrectly made ("It tasted like they dumped vinegar in it"); strangely seasoned ("They had stuff with a lot of curry in it and that tasted kind of weird too"); and just not satisfying ("Neither dish was filling"), all the basic expectations about food are being upset. Eating is supposed to be a familiar, pleasant, sensual event shared with family, friends, and honored guests who have crossed the "threshold of intimacy" that separates meal sharers from strangers (Douglas 1975:257). Meals are not supposed to be conflict-generating events that challenge one's basic assumptions. Confronted with these unusual and coercive meals, Chapman and Talbot were not only unwilling consumers but also confused about how to interpret the behavior. Were the encampment women breaking all the rules of etiquette, good taste, and decorum by not accommodating their "guests" "tastes, or were the "guests" the ones who were being ungrateful and rude? Talbot and Chapman got so frustrated with the behavior of the encampment women, says Chapman, that they jokingly debated "which one of the lesbian witches would taste best barbequed on a bonfire."

Moreover, these aspects of taste and choice had implications beyond mealtimes. Dietary practices are often taken as powerful indicators of both individual and social health. For example, Americans tend to promote the idea that dietary habits affect the mental stability as well as the physical well-being and even the moral rectitude of the individual (B. Turner 1984:77). Many American diet programs and books promise multifaceted benefits, claiming that followers will live longer, feel happier, 
have better mental capabilities, and have a better outlook on life. One patient who followed the Pritikin diet, for instance, reported:

I've never felt this good in my life, but I don't know why. I felt well when I went to the [Pritikin] Center, but I feel more alive, more alert now. Maybe it's just the weight loss.

It's a kind of joie de vivre. I hope you won't laugh when I tell you that I feel like laughing and singing a lot. I never felt this way before-except when I had some very good news. There's a correlation, I feel, between a feeling of well-being and mental and emotional stability. (Pritikin and McGrady 1979:99)

Dietary management of the body is considered necessary not just for individual health but also for group stability. As Bryan Turner notes, "Diet is a cultural practice regulating quantities and types of food for designated categories of person" (I984:I70). It is useful and necessary, therefore, for identifying and maintaining social categories. Serving or eating the right food "conveys the message that proprieties are being observed" (Murcott I 983:2), that the world is in its proper order. The choice of the correct food, designated by the judgment of "good taste," is "simultaneously a question of aesthetics and ethics. Eating what is 'good for you' is always more than a matter of mere nutritional value" (Atkinson 1983:I7). It is also a matter of knowing what defines you as a proper member of your chosen community.

These relations between dietary habits and the social system are played out in a variety of ways in everyday life. For example, different foods have differential values to the variously situated members of a society. In the American tradition red (bloody) meat has until recently been designated as the most valued food, followed by "bloodless" poultry and fish, eggs and cheese, and, at the bottom, fruit, vegetables and grains. Some believe that it is the redness or the bloodiness of meat that gives it preeminence. Julia Twigg claims that blood has historically been significant because it is "associated with ideas of the living force, carrying aspects of energy and violence, of the arousal and stimulation of the passions and of the distillation of the particular essence of the animal and thus of animality itself" (I $983: 22-23$ ).

We can see the connections among food categories, the hierarchy of social relations, and the categorization of persons when we look at who is supposed to eat red meat in the United States. Despite concerns about fat and cholesterol, red meat meals are considered necessary particularly for 
males because of the perceived fit between the animal qualities Twigg lists and proper masculinity. A failure to ingest enough red meat could potentially leave the question of a man's masculinity in doubt. In a television commercial for the beef industry, the rugged and very "masculine" actor James Garner promoted the superiority of beef over other types of food using the slogan, "Beef. Real food for real people." Beef eaters are still perceived, despite some changes in American dietary habits, as tall, muscular, well-fed animals, and those who consume little beef are seen as effeminate and weak, questionable "real men." More recent beef industry ads have replaced the aging and less than healthy Garner with muscular athletes and younger celebrities. A billboard in North Dakota promotes beef with the slogan "Because the West wasn't won on salad."

A discussion of food preferences, then, talks not only about what and how to eat but also about the moral and cultural implications of these choices. Food preferences are a very visible way to confirm membership in a category and to judge the category of the person in question. Because food is such a strong indicator, food-related metaphors are often useful for talking about the relations between things inside and outside a category. Just as the digestibility of food can indicate category membership, so the "digestibility" of ideas can indicate whether they are acceptable or not within a category. Problematic ideas can be "food for thought," but more likely they are "difficult to swallow" or they can "turn one's stomach" and "not sit well" in the (digestive) system.

If food is "one of the means by which a society creates itself and acts out its aims" as Margaret Visser claims (I986:I2), the encampment food habits were revealing to Lucinda Talbot and Sharon Chapman an unexpectedly un-American and antisocial world. Vegetarianism, they came to believe, was a symbol and a product of antisocial political aims, not a natural choice based on apolitical bodily needs or urges. Talbot and Chapman believed their own diet was designed to fulfill natural needs and appetites, those nutritional requirements of the body that must be met for continued existence. Their several references to the outside authority "Nutrition" suggest that proper dietary guidelines have been scientifically and objectively defined. Appealing to this authority by expressing the dangers of the encampment eating habits in nutritional terms ("It doesn't hurt people to eat a vegetarian diet provided that they follow the balanced food group type of thing") lent legitimacy to their judgment that the (eating) behaviors of the encampment women were unacceptable.

These two women believed that others at the encampment were using food to fulfill an appetite based on political desire rather than bodily, 
natural needs. The Encampment women were unwilling to stay within the bounds of their natural appetites, were indulging in unnatural choices that perhaps shouldn't be made. These choices involve a redefinition of what is proper and natural for women's bodies, and what control women should or should not have over their bodily functions. These are central issues of feminist activism. The female body has often been the site of disputed discourses, political controversy, and power struggles. Thus the control that women seek over their bodies is manifested in challenges to established notions about women's sexuality, motherhood, lesbianism, abortion, rape, birth control, battering, and the public and private roles of women. But the issue of control over women's bodies has divided feminists as often as it has united them, for there is no standard feminist stance on any of these controversial matters. Nevertheless, because women are seen as written or determined through their bodies in a way that men are not, feminists do not ignore the political and discursive implications of taking the power to define the female body.

Chapman and Talbot did not express a feeling of being out of control of their own bodies except when the encampment tried to force a vegetarian diet on them. Both saw their own food habits as proper for themselves, as logical and freely chosen, and as superior to those of the encampment. They were surprised and offended when others seemed unwilling to share the superior food they had brought with them. The encampment cooks shunned the canned chow mein they donated, for example, and it never appeared during mealtime. "To the best of my knowledge," said Chapman, "it's still there." This experience made them more wary about sharing their food. Although they wanted the encampment women to know that vegetarianism was unacceptable, they were not willing to give up their own secure provisions and abandon dietary control just to make this point.

The refusal to share their food provided Chapman and Talbot with some autonomy but not complete peace of mind. They still felt compelled to conform to the vegetarian standard in public. They claimed they had been misled about the encampment's endorsement of vegetarianism to the exclusion of all other eating habits, and in fact, none of the orientation material handed out in 1983 , including the Resource Handbook, mentions a vegetarian meal policy. The handbook has no section on food, and the supplementary orientation handout did not mention the use of meat. Nor did the "respected policies," the loose "rules" that had previously been agreed on, mention vegetarianism.

Although Talbot and Chapman were correct in saying that the encamp- 
ment did not specifically ban meat, only an outsider, someone not previously active in feminism, would have been unacquainted with the association between a vegetarian eating style and feminist activism. One vegetarian-feminist who was later to be active at the peace encampment wrote in a 1982 article that vegetarianism was a political act akin to feminism and nonviolence (Salamone 1982). Like feminist nonviolence, vegetarianism was seen as necessary for the change back to a "natural" order of social and ecological peace and harmony.

Feminism has been strongly attracted to vegetarianism because both "isms" propose a basic reordering of the world: vegetarianism challenges the hierarchy of food values and the resulting relationship with animals and "nature," and feminism challenges the hierarchy of "male" values and its attendant social relations. In this interpretation, Twigg says, "meat, both through the cruelty involved in its production and daily acquiescence to this involved in eating it, is here seen to stand for egotism, selfishness and coldness of heart that denies the natural empathy between human beings and beasts. Vegetarianism from the late nineteenth century and before has been linked with a growing ideology of intuition that has revolted against what it see as the coldness of rationality and the fragmented nature of modern consciousness" (I983:27-28). These same ideas were also at work at the encampment. Like many habits that are so familiar to a group as to seem scarcely worthy of comment, vegetarianism was taken for granted in this feminist community. It was a basic assumption about encampment participants; therefore, the choice of whether or not to abide by this unwritten code was one way to judge how well a person fit into the encampment community.

Chapman felt that she was generous in her efforts to tolerate the peace encampment women despite her differences from them. She could understand and accept vegetarianism, however unpleasant, as an acceptable alternative, but for her lesbianism and witchcraft were religious "abominations" that were completely unacceptable. She explained, "Now I was putting up with a lot just being there, and not saying to them, this is biblically wrong, because things like this can bring the whole land under judgment from God."

Talbot's approach was a bit different. She tended to be more analytical in her descriptions and discussions, always attempting to get the facts "straight," to choose her words carefully and precisely, and to comment only on those things she herself actually observed. For her, the normal, acceptable world was not based on or explained by religious convictions as it was for Chapman. Talbot expressed her dissatisfaction with the encamp- 
ment in practical rather than religious or personal terms and according to criteria she considered easily specifiable and logical. For her, the problem with the women of the encampment was that their beliefs and actions were not genuine or convincing; rather, they seemed hastily formed, carelessly practiced, and not supported by scientific research.

Talbot seemed somewhat interested in the witchcraft and spiritualism of some of the encampment women but hated to see them dissolve into silliness. She described a witch she had met at the encampment: "She said she used to be a Quaker and then she read a book that told about how women are oppressed by all Christian churches, and then she stopped being a Quaker and started being a witch. Yeah, I remember Katy; she said she flew around the Encampment but actually she drove a car. Really!" Talbot has a portrait of herself on the wall of her apartment in Elmira. In this portrait, which was drawn by a friend, she has flaming red hair, a symbolically painted face, and a bright yellow, pointed aura. In discussing the portrait, Talbot revealed that she is not at all opposed to alternative forms of spirituality. It is just that these alternatives need to be approached carefully so that the experience can be "genuine." She did not reject witchcraft and spirituality as much as take a different approach toward them:

If I were to get interested in witchcraft, I would seek out someone who had a coven, and I would be a learner before I was a teacher. It seems to me that their witchcraft was, is, as shallow as their politics. ... Now if they had been been English, if they had gone through the apprenticeship to be an English witch or if they had gone through the apprenticeship to be American ... shamans ... but the fact is they didn't seem to have the training. . . . You don't form a coven by finding thirteen like-minded people and taking off their clothes and dancing.

Talbot treated lesbianism with similar scientific detachment. Rather than express surprise or disgust at lesbianism as Chapman did, Talbot attempted to comprehend it by quoting "scientific" sources:

Right after this [the Encampment] happened there was an article in the Psychology Today, and it stated that there was a theory that the majority of lesbians had been sexually abused. Well, I don't know, 33 percent of the whole female population has been sexually abused so, and the proportions [of lesbians in the general population] are not like that. And then there was this other article that said that, the DES children who 
were treated in the embryo with male hormones were 25 percent lesbian, which is a good portion... so, [sigh] you do wonder.

Lesbianism for Talbot wasn't an abomination so much as just incomprehensible, especially when women told her that they were lesbians because it was the politically correct thing to do. Being a lesbian by choice didn't make sense to her. What she had read seemed to indicate that there were biological reasons for the development of lesbians. Choosing to be a lesbian seemed to be just another example of disingenuousness. In her view physical causes left no room for conscious choice. Like vegetarianism, political lesbianism seemed unnatural to Talbot because it defied natural bodily needs and desires.

Talbot's and Chapman's difficulties with lesbianism (that it was immoral or a false issue or both) are prevalent in feminism, as in the larger culture. Defining homosexuality as a sexual "preference" (as some factions of both the heterosexual and the homosexual communities do) reinforces the idea that a decidedly conscious choice is involved, but lesbianism as a possible choice presents several problems for the heterosexual community in general and for nonlesbian feminists in particular. The association of feminism with lesbianism has always been a touchy subject in feminist political circles. Some lesbian feminists, most notably Adrienne Rich, have designated heterosexuality as, in Ann Ferguson's words, "the key mechanism underlying and perpetuating male dominance" (Ferguson I 98I: I 59). Heterosexual women are accused of being implicated in this system of dominance, and a lesbian consciousness or lifestyle has often been promoted as the only correct political position. Heterosexual women in turn have blamed lesbians for the failure of feminist principles to be more widely accepted. Many feminists consider the identification of feminism with lesbianism undesirable; they prefer to focus attention away from sexuality and other controversial issues. Lindsy Van Gelder comments in a Rolling Stone Magazine article on lesbians, including some encampment women, “The mainstream women's movement . . . is sometimes similarly queasy about word getting out to the New Right that, yes, feminism can turn you into a lesbian" (I982:I4).

Van Gelder notes that political lesbianism is also an issue within the lesbian community itself. Just as it challenges the notion of what is natural in the heterosexual world, political lesbianism challenges the "natural" basis of lesbian identity, and in either community such a challenge is often unwelcome. Van Gelder explains: "The gay movement . . . has a vested interest in pushing the theory (advanced by a number of respected sex 
researchers) that sexual preference is set in bronze by the time a person is three years old or so" (ibid). Political lesbianism is to some extent considered a lesser form of lesbianism in both the heterosexual and the lesbian community. Van Gelder notes that some "old time dykes," women who acknowledged being lesbians before it was the politically correct thing to do, are suspicious of women who are attracted to lesbianism for its rhetorical power. One lesbian told Van Gelder that such women seemed less committed to gay sexuality, seemed to "go back to pricks" after the attraction of lesbianism had worn off. Whether or not these characterizations are widely held in lesbian circles, there does appear to be a fair amount of discussion and disagreement about "choosing lesbianism" as a political statement. As one contributor to a lesbian newsletter explains in a letter titled "Choosing Lesbianism," "I often hear lesbians talk about their sexual 'preference' and how they have chosen to love women. Maybe I'm weird but I really can't imagine sitting down and choosing to love someone. I seriously chose to love men for thirty years but, try as I might, I could never love one. ... If I could, I would choose to be a lesbian. As it is-I am one" (Lesbian Connections, I985: IO).

That Talbot and Chapman were able to come to the encampment and participate in its activities shows that the encampment did indeed attract a wide range of women. But although the encampment was open to all women, not all women felt equally welcome or at home there. Like any community, no matter how feminist its politics, the encampment had criteria for judging the "fitness" of the women who wanted to participate. Without this judgment, there would be no way to define who was inside the group and who was out.

At the encampment, this judgment of fitness was not always overt. Often it was a much subtler determination of who was "politically correct" and who was not. The criteria for political correctness in this combined feminist-lesbian-peace-activist community cannot be definitively specified because they shifted with the ever-changing membership of the encampment. But at the beginning, at the time that Chapman and Talbot were there, a woman's ability and willingness to accept and not to criticize the "lesbian-vegetarian-witches," as these two women called them, was a good basic way to judge if a woman shared the political views of most encampment women. Out of the need to construct a shared community identity, the women developed a complex folk categorization that was used to classify participants for community membership.

The lesbian-vegetarian-feminist-spiritualist was taken as the prototype (see Lakoff 1987:87), or best example, of the politically correct woman, 
but other women were not completely or automatically excluded from acceptance. Rather, all women were potential community members. If some did not fit the prototype perfectly, many "excuses" could be employed to allow them entry to the category despite their lapses. These excuses explained why these women could not or would not want to be politically correct at the moment. Thus, a woman who had been battered or who was black or poor or who was an older, nonpolitical lesbian had a reason, derived from her position in the patriarchal society, for not meeting the prototype, and she was excused. As two peace encampment women joked, feminists make so many different kinds of excuses to avoid excluding any women from their community that they end up with such categories as "Jewish, middle-aged feminist with two kids" in order to account for all these deviations.

The encampment afforded the opportunity for women whose politics were not usually considered correct (nonlesbians, nonvegetarians, women who approved of violent actions or didn't like feminist process and consensus) to measure their loyalty to and appreciation of these criteria for shared community. Even if a women were not a prototypical lesbianvegetarian-witch herself, she could gain some acceptance if she avoided criticism of the prototype. The fitness of a woman visiting the encampment would be judged according to this protocol, and the effects of actively rejecting the encampment system can be seen in the experience of Talbot and Chapman.

These two women created a dilemma for the encampment. By its own express policy of openness to diverse women, the encampment had to attempt to accommodate Talbot and Chapman's differences. But at the same time, the two Elmira women caused a furor that threatened the encampment's internal coherence. The threat was not just that they disagreed with what was going on at the encampment; many women disagreed with or could not meet the criteria for political correctness, and some even objected to the unspoken but obvious hierarchy the criteria created. No others, however, challenged these issues as vehemently, publicly, and persistently as did Chapman and Talbot.

The peace encampment decided to deal with the two in several ways. One was to see the women's challenge not as a deliberate critique but as an unfortunate incident beyond Talbot and Chapman's personal control, caused by their particular circumstances in the patriarchal society. Encampment members speculated variously that their complaints and their resulting divisive actions might be based on such diverse elements as their physical condition, their religions, their materialistic attitude, their social 
class, and their unfamiliarity with feminism. Several of the encampment organizers tried to describe why Chapman and Talbot became a problem:

Shad: They were women who had been involved in peace issues but they had never really been involved in an alternative culture.

Jody: I don't know what class they were, maybe working class.

Shad: I would say they were probably working class.

Jody: And they were very unusual. Were they Quaker women?

Michelle: No, they were Jehovah Witness.

Jody: Oh dear.

Shad: Was it Jehovah's Witnesses?

Michelle: I think they were Jehovah Witness.

Shad: I never knew that.

Some of the encampment women based their explanation of Chapman and Talbot's behavior on nutrition, in much the same way as Chapman and Talbot had judged the encampment. They believed that the Elmira women's diet was inappropriate for the situation and left them emotionally and physically unfit. One herbal healer said they were not drinking enough water and were overweight. Another woman said they had problems because they ate too much sugar. The encampment thus had to create an image of these two women that could explain why and how they could behave in this way in the context of a supposedly unified female space.

To admit that the women had legitimate complaints that should have been dealt with more carefully would be to admit that the encampment was not as cohesive as it needed to appear. The public representation of the encampment had to be that of an internally consistent and cooperative community, a model of peaceful existence unlike the outside world. If this image were destroyed, the entire basis of the encampment as a viable alternative to the patriarchy could be called into question.

The encampment women made a concerted effort to counter Talbot and 
Chapman's accounts and to maintain an image of internal tranquillity. In attempting to explain to the newspapers the encampment's view of what had happened with the two Elmira women, one encampment woman said, "I don't think there was nearly as much antagonism toward the women as they perceived" (Finger Lakes Times, July I I, 1983). Others said that they had simply mistaken feminist spiritualism for witchcraft or were claiming to see things no one else had witnessed.

It became necessary for the encampment to put all of its processual mechanisms into full gear in order to deal with the two women. At Talbot and Chapman's request, meetings were called to rediscuss the flag issue, and the two women attempted to make themselves heard at evening circles. They complained about the anarchists who destroyed flags, and other women countered that Chapman and Talbot had been disruptive because they carried around little American flags for several days. They also wore rosaries around their necks to counter the powers of the witches and tried to get the encampment women to see that the way they were living was offensive to the surrounding communities. Like the early Encampment organizers, they feared that some "good old boys" from the area would come to the peace camp and "bash their heads" unless they stopped the lesbianism, witchcraft, goddess worship, and flag stomping.

These two women could not accept this world of lesbian-vegetarianwitches. The peace camp women seemed to be asking them to change just about everything that had always seemed right and natural and comfortable. When they finally had more encampment food and encampment ideas than they could stand, they took drastic action. They began by cutting all the yarn webs at the encampment with scissors and threatening to throw paint on a large web painted on the side of the barn. When the encampment women tried to stop them, Chapman and Talbot claimed they were legitimately using the encampment's own protest techniques to express their dissatisfaction with the system:

Chapman: Well we asked them part of their theory about violence, and they were saying that violence against property is not violence, defending the fact that they went and did damage and stuff to the Depot.

Talbot: So we violated some property.

Chapman: So we went over and cut the webs, and they said you can't do that, that's violence. And we said violence against property is not violence; you told us so yourself. 
By cutting the web of the encampment rather than staying within its protective bounds, the two Elmira women were challenging and rejecting some of the basic premises of the encampment. The web was supposed to represent unity despite diversity, the interconnectedness of all issues (including the rights to be "lesbian-vegetarian-witches" and to practice alternative sexual, religious, and eating behaviors), and the power women can have by joining together. The breaking of the web, both the symbolic web and the communal web of the encampment, had the power to destroy the encampment's representation of itself. Perhaps even more significantly, in vocalizing their problems with the peace encampment, the two women raised the question of the differences within the encampment, which until that time had not often been publicly acknowledged. One of the encampment organizers recalled Sharon and Lucinda's departure with humor but also chagrin: "They packed, they had their boyfriend come, and they loaded up their stuff and they went away. And we go, "Who were those two masked women?' [laughter] as the encampment is in shambles."

On July 7, I983, three days before she left the encampment, Sharon Chapman wrote the following poem and posted it on a bulletin board at the peace camp:

I don't need to be told

That I am different from you.

I can see it for myself.

It's okay with me.

You have the right to be you

as much as I have to be me.

Differences are special

because you see the beauty

I might miss

and I can show you

The wonders I see.

But when you use the differences

to shut me out

to push me away

Then you are wrong

you deprive yourself and me.

If we add our differences together

we increase.

If you refuse to know me

we decrease. 
And that's not right.

We both lose.

And who wants to be a loser?

In 1985 Chapman wrote the following note to explain this poem:

I don't know if I feel this way now. I think when I wrote this poem I was trying to make them see that they have to accept people as they are, that different opinions make life better. But they were real heavy into the "I'm right and that's it" idea, and they had no more idea of being tolerant than they had of making love with men. I think it would have taken a nuclear bomb to open their minds to thinking again - they were that narrow-minded and intolerant. Phooey on them!

And I've definitely changed about one thing: I don't see why I should be tolerant of someone who won't be tolerant of me. I'll pray for themthat's my duty as a Christian. But associate with that kind again? No way. 